\title{
Evaluation of Some Haematological Features of Tandem Spinal Stenosis Subjects In a Tertiary Hospital in Enugu, South East, Nigeria
}

\author{
Emmanuel Ifeanyi Obeagu ${ }^{1 *}$ and Getrude Uzoma Obeagu ${ }^{2}$ \\ ${ }^{1}$ Department of Health Services, Michael Okpara University of Agriculture, Nigeria \\ ${ }^{2}$ Department of Nursing Science, Ebonyi State University, Nigeria
}

Submission: November 14, 2017; Published: November 28, 2017

*Corresponding author: Emmanuel Ifeanyi Obeagu, Department of Health Services, Michael Okpara University of Agriculture, Umudike, Abia State, Nigeria, Tel: +2348037369912; Email: emmanuelobeagu@yahoo.com

\begin{abstract}
Tandem spinal stenosis (TSS) occurs as a result of spondylotic degeneration associated to symptomatic canal narrowing of multiple areas of the spine resulting to neurologic compression. It occurs more in elderly, more in male and the obese. The study was done to evaluate haematological features of tandem spinal stenosis in subjects attending a tertiary hospital in Enugu. The results showed significant increase $(\mathrm{P}<0.05)$ in ESR and neutrophil of tandem spinal stenosis (TSS) subjects $(38.0 \pm 2.6 \mathrm{~mm} / \mathrm{hr}, 66.0 \pm 6.2 \% 0$ compared to the control $(10.2 \pm 0.8 \mathrm{~mm} / \mathrm{hr}, 58.0 \pm 7.5 \% 0$, significant decrease $(\mathrm{P}>0.05)$ in lymphocytes, red blood cell, haemoglobin and packed cell volume of the tandem spinal stenosis (TSS) subjects $\left(34.0 \pm 8.1 \%, 3.67 \pm 0.5 \times 10^{12} / \mathrm{L}, 11.0 \pm 0.6 \mathrm{~g} / \mathrm{dl}, 3.0 \pm 8.6 \%\right)$ compared to control $\left(42.0 \pm 12.0 \%, 4.76 \pm 0.7 \mathrm{X} 10^{12} / \mathrm{L}, 14.3 \pm 0.5 \mathrm{~g} / \mathrm{dl}, 43.0 \pm 5.2 \%\right)$ and no significant difference $(\mathrm{P}>0.05)$ in total white cell, mean cell volume, mean cell haemoglobin, mean cell haemoglobin concentration of the tandem spinal stenosis (TSS) subjects $\left(4.9 \pm 0.2 \times 10^{9} / \mathrm{L}, 89.91 \pm 7.9 \mathrm{fl}, 29.97 \pm 2.7 \mathrm{pg}, 333.33 \pm 15.0 \mathrm{~g} / \mathrm{l}\right)$ compared to control $\left(5.0 \pm 0.5 \mathrm{X} 10^{9} / \mathrm{L}, 90.34 \pm 4.3 \mathrm{fl}\right.$, $30.11 \pm 3.4 \mathrm{pg}, 333.26 \pm 23.0 \mathrm{~g} / \mathrm{l}$ ) respectively. It shows that tandem spinal stenosis leads to anaemia and inflammation as shown by the decrease in the red blood cell, haemoglobin, packed cell volume and increased in neutrophil as a sign of oxidative stress which could be a result of inflammation or the pains, it could also lead to immunodeficiency as seen in reduction in lymphocytes.
\end{abstract}

\section{Introduction}

Tandem spinal stenosis (TSS) is reported as an infrequent, but medically crucial phenomenon; with a stated incidence of between 5 and $28 \%$ of spinal stenosis cases. Tandem stenosis is a distinct syndrome, generally as a result of spondylotic degeneration linked to symptomatic canal narrowing of multiple areas of the spine leading to significant neurologic compression [1-3]. Importantly, patients with tandem stenosis will present with signs of intermittent neurogenic claudication, progressive gait disturbance, and findings of mixed myelopathy and polyradiculopathy in both the upper and lower extremities. Frequently it is not until after surgical correction of the primary symptomatic area that the second area of symptomatic stenosis becomes evident [1-3].

It is strongly shown that cervical spondylotic myelopathy (CSM) is the highest common cause of spinal cord injury in older adults [4-6]. It is reported that degenerative changes with radiographic evidence of compression are evident in up to $50 \%$ of the population older than 55 , but only $10 \%$ proceed to have symptoms of nerve root or spinal cord compression. The pathology of spondylotic myelopathy is caused by degenerative changes of the disc, facet joints, hypertrophy of the ligamentum flavum, uncovertebral hypertrophy, and the possibility of a congenitally small central canal [7-10]. This condition typically occurs between the ages of 50-70, with complaints of insidious onset, 3:2 male/female respectively [11]. The primary initial symptoms of patients with CSM are frequently gait disturbances due to compression or degenerative changes of the spinocerebellar and corticospinal tracts [12]. This is characterized by a spastic or ataxic gait with a wide base of support and stooping posture. A loss of fine motor control is the most frequent complaint, typically manifesting as complaints of clumsy hands and/or difficulty writing [13-15].

Incontinence of urine and occasionally of bowel may be present in advanced cases. Cases of primary central canal stenosis may not include radicular symptoms to the upper extremities, but will present with long tract signs only. The presentation during physical examination will include: generalized hyperreflexia, clonus more likely in the lower than upper extremities, a positive Hoffmann's sign, a positive L'hermitte's sign, and 
positive Babinski reflexes [13]. Lumbar spinal stenosis (LSS) is a commonly encountered condition, and may also occur as a component of TSS. The typical LSS patient is more likely to be male, in the fifth or sixth decade of life [16]. Clinically, the most frequent signs are leg pain, which is most often exacerbated by walking or extension and relieved with flexion; altered reflexes; weakness in a myotomal distribution; and decreased sensation to touch and vibration. Gait is frequently flexed and with a wide base of support $[17,18]$, similar to that of CSM. Cauda equina syndrome (CES) is a rare, but serious, complication of LSS. Typical early signs and symptoms include low back and leg pain as well as abnormalities of the bulbocavernosus and ischiocavernosis reflexes $[19,20]$.

There is paucity of published research works on haematological features of tandem spinal stenosis in this part of the world. It is pertinent to carry out this research for proper diagnosis and management of the patients.

\section{Aim}

The aim of the study was to determine the hematological features of Tandem Spinal Stenosis subjects in Enugu, South East, Nigeria.

\section{Materials and Method}

\section{Study Area}

The study was done in National Orthopaedic Hospital, Enugu, Nigeria.

\section{Study Design}

The study is a hospital based prospective cross sectional study using purposive sampling technique from January 2016 to May 2017.

\section{Subjects}

The subjects comprised of a total of sixty (60) subjects, 30 subjects were Tandem Spinal Stenosis (TSS) patients aged 60-75 years (20 females and 10 males) and 30 (15 females, 15 males) subjects were apparently healthy individuals aged matched as the control.

\section{Ethical Consideration}

This study was performed in compliance with the guidelines of the Helsinki Declaration on biomedical research on human subjects. It was a prospective study, and confidentiality of the identity of the patients and personal health information was maintained.

\section{Statistical Analysis}

The results were presented in tables as mean and standard deviation and student t-test used for analysis and the level of significance was set at $\mathrm{P}<0.05$

\section{Haematological Investigation}

The haematological investigations were done using Mindray BC-5300. The haematological parameters investigated include
Erythrocyte Sedimentation Rate (ESR) total white blood cells (WBC), neutrophils, lymphocytes, red blood cells, haemoglobin, packed cell volume (PCV), mean cell volume (MCV), mean cell haemoglobin $(\mathrm{MCH})$ and mean cell haemoglobin concentration (MCHC).

\section{Results}
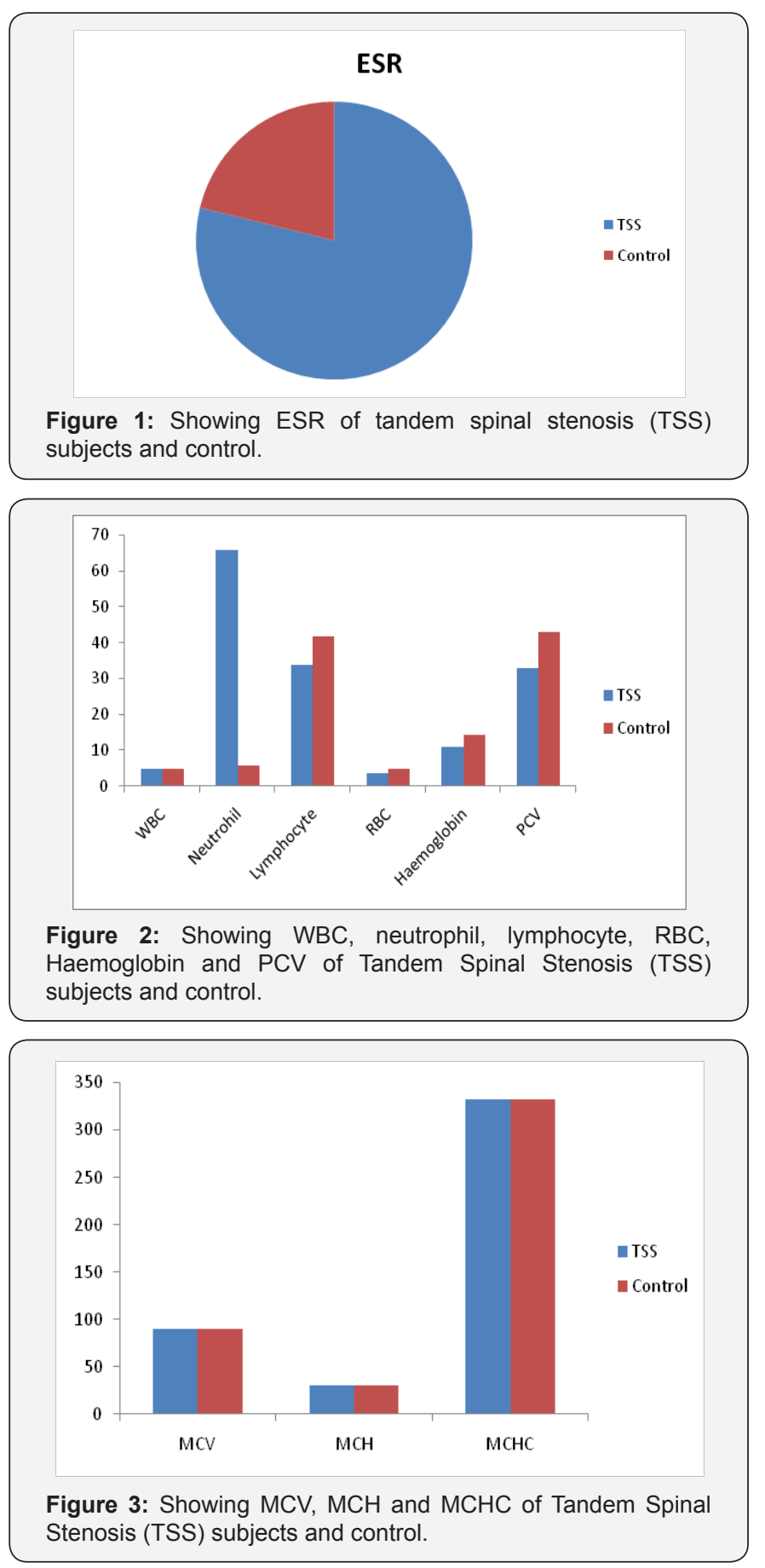

The results showed significant increase $(\mathrm{P}<0.05)$ in ESR and neutrophil of tandem spinal stenosis (TSS) subjects $(38.0 \pm 2.6 \mathrm{~mm} / \mathrm{hr}, \quad 66.0 \pm 6.2 \% 0$ compared to the control $(10.2 \pm 0.8 \mathrm{~mm} / \mathrm{hr}, 58.0 \pm 7.5 \% 0$, significant decrease $(\mathrm{P}>0.05)$ in lymphocytes, red blood cell, haemoglobin and packed cell 
volume of the tandem spinal stenosis (TSS) subjects $(34.0 \pm 8.1 \%$, $3.67 \pm 0.5 \times 10^{12} / \mathrm{L}, 11.0 \pm 0.6 \mathrm{~g} / \mathrm{dl}, 3.0 \pm 8.6 \%$ ) compared to control $\left(42.0 \pm 12.0 \%, \quad 4.76 \pm 0.7 \quad \mathrm{X} 10^{12} / \mathrm{L}, \quad 14.3 \pm 0.5 \mathrm{~g} / \mathrm{dl}, \quad 43.0 \pm 5.2 \%\right)$ and no significant difference $(\mathrm{P}>0.05)$ in total white cell, mean cell volume, mean cell haemoglobin, mean cell haemoglobin concentration of the tandem spinal stenosis (TSS) subjects $\left(4.9 \pm 0.2 \quad \mathrm{X} 10^{9} / \mathrm{L}, 89.91 \pm 7.9 \mathrm{fl}, \quad 29.97 \pm 2.7 \mathrm{pg}, \quad 333.33 \pm 15.0 \mathrm{~g} / \mathrm{l}\right)$ compared to control $\left(5.0 \pm 0.5 \mathrm{X} 10^{9} / \mathrm{L}, 90.34 \pm 4.3 \mathrm{fl}, 30.11 \pm 3.4 \mathrm{pg}\right.$, $333.26 \pm 23.0 \mathrm{~g} / \mathrm{l}$ ) respectively (Table 1) (Figures 1-3).

Table 1: Comparison of haematological features of the tandem spinal stenosis (TSS) subjects to control.

\begin{tabular}{|c|c|c|c|c|c|c|c|}
\hline Parameters & & & TSS & & & Control & $\begin{array}{c}\text { Level of } \\
\text { Significance }\end{array}$ \\
\hline ESR $(\mathrm{mm} / \mathrm{hr})$ & & & $38.0 \pm 2.6$ & & $10.2 \pm 0.8$ & & $\mathrm{p}<0.05$ \\
\hline WBC (X109/L) & & $4.9 \pm 0.2$ & & $5.0 \pm 0.5$ & & $\mathrm{P}>0.05$ & \\
\hline Neutrophil (\%) & $66.0 \pm 6.2$ & & $58.0 \pm 7.5$ & & $\mathrm{P}<0.05$ & & \\
\hline Lymphocyte (\%) & & $34.0 \pm 8.1$ & & $42.0 \pm 12.0$ & & $\mathrm{P}<0.05$ & \\
\hline RBC (X1012/L) & & $3.67 \pm 0.5$ & & $4.76 \pm 0.7$ & & $\mathrm{P}<0.05$ & \\
\hline Haemoglobin (g/dl) & & $11.0 \pm 0.6$ & & $14.3 \pm 0.5$ & & $\mathrm{P}<0.05$ & \\
\hline PCV (\%) & & & $33.0 \pm 8.6$ & & $43.0 \pm 5.2$ & & $\mathrm{P}<0.05$ \\
\hline MCV (fl) & & & $89.91 \pm 7.9$ & & $90.34 \pm 4.3$ & & $\mathrm{P}>0.05$ \\
\hline $\mathrm{MCH}(\mathrm{pg})$ & & & $29.97 \pm 2.7$ & & $30.11 \pm 3.4$ & & $\mathrm{P}>0.05$ \\
\hline $\mathrm{MCHC}(\mathrm{g} / \mathrm{l})$ & & & $333.33 \pm 15.0$ & & $333.26 \pm 23.0$ & & $\mathrm{P}>0.05$ \\
\hline
\end{tabular}

ESR: Erythrocyte Sedimentation Rate; WBC: Tostal White Cell Count; RBC: Red Blood Cell; PCV: Packed Cell Volume, MCV: Mean Cell volume; MCH: Mean Cell Haemoglobin; MCHC: Mean Cell Haemoglobin Concentration; TSS: Tandem Spinal Stenosis Subjects

\section{Discussion}

Haematological investigations especially full blood counts are good indicators in health and disease states. It helps to understand the real disease presentation juxtaposed to the clinical features in the patients. Tandem spinal stenosis (TSS) is becoming a major threat especially from the middle aged to the elderly especially in the obese individuals and trauma patients [21-24]. The study showed that there was elevation in erythrocyte sedimentation rate and neutrophil of tandem spinal stenosis subjects compared to the control. This could be linked to hypervolaemia and oxidative stress which may lead to increase release of neutrophil to the circulation. The study also showed significant decrease in lymphocytes, red blood cells, haemoglobin, packed cell volume of the tandem spinal stenosis subjects compared to the control. The decrease in lymphocytes may expose the subjects to immunodeficiency. This could lead to opportunistic infections in the patients. Decrease in red blood cells, haemoglobin and packed cell volume shows that the tandem spinal stenosis patients are exposed to anaemia. This may have adverse effect on their vitality of life. This may be associated with bone marrow suppression and increased pooling of cells to the spleen. There could be delayed and slow erythropoiesis in the patients.

\section{Conclusion}

It shows that tandem spinal stenosis leads to anaemia and inflammation as shown by the decrease in the red blood cell, haemoglobin, packed cell volume and increased in neutrophil as a sign of oxidative stress which could be a result of inflammation or the pains, it could also lead to immunodeficiency as seen in reduction in lymphocytes. This should be of a great guide to neurosurgeons and orthopaedic surgeons in the management of tandem spinal stenosis.

\section{References}

1. LaBan MM, Green M (2004) Concurrent (tandem) cervical and lumbar spinal stenosis. Am J Phys Med Rehabil 83(3):187-190.

2. Dagi TF, Tarkington MA, Leech JJ (1987) Tandem lumbar and cervical spinal stenosis: natural history, prognostic indices, and results after spinal decompression. J Neurosurg 66(6): 842-849.

3. Kikuike K, Miyamoto K, Hosoe H, Shimizu K (2009) One-staged combined cervical and lumbar decompression for patients with tandem spinal stenosis on cervical and lumbar spine. J Spinal Disord Tech 22(8): 593-601.

4. Klineberg E (2010) Cervical spondylotic myelopathy: a review of the evidence. Orthop Clin North Am 41(2): 193-202.

5. Gore DR, Sepic SB, Gardner GM (1986) Roentgenographic findings of the cervical spine in asymptomatic people. Spine 11(6): 521-524.

6. Boden SD, Davis DO, Dina TS, Patronas NS, Wiesel SW (1990) Abnormal magnetic resonance scans of the cervical spine in asymptomatic subjects. A prospective investigation. J Bone Joint Surg Am 72(8): 1178-1184.

7. Tracy JA, Bertelson JD (2010) Cervical Spondylotic Myelopathy. Neurologist 16(3): 176-187.

8. Bernhardt M, Hynes RA, Blume HW, White AA (1993) Cervical spondylotic myelopathy. J Bone Joint Surg Am 75(1): 119-128.

9. Ferguson RJL, Caplan LR (1985) Cervical spondylitic myelopathy. Neurol Clin 3: 373-382.

10. Ogino H, Tada K, Okada K, Yonenobu K, Yamamoto T, et al. (1983) Canal diameter, anteroposterior compression ratio, and spondylotic myelopathy of the cervical spine. Spine 8(1): 1-15.

11. Bartleson JD, Deen HG (2009) Spine disorders: medical and surgical management. Cambridge University Press, New York, USA. 
12. Geck MJ, Eismont FJ (2002) Surgical options for treatment of cervical spondylotic myelopathy. Orthop Clin North Am 33(2): 329-348.

13. Clark CR (1988) Cervical spondylotic myelopathy: history and physical findings. Spine 13(7): 847-849.

14. Cook C, Roman M, Stewart K, Leithe LG, Isaacs R (2009) Reliability and diagnostic accuracy of clinical special tests for myelopathy in patients seen for cervical dysfunction. J Orthop Sports Phys Ther 39(3): 1721717218.

15. Cook C, Brown C, Isaacs R, Roman M, Davis S, et al. (2010) Clustered clinical findings for diagnosis of cervical spine myelopathy. J Man Manip Ther 18(4): 175-180.

16. Fritz JM, Delitto A, Welch WC, Erhard RE (1998) Lumbar spinal stenosis: a review of current concepts in evaluation, management and outcome measures. Arch Phys Med Rehabil 79(6): 700-708.

17. Nowakowski P, Delitto A, Erhard R (1996) Lumbar spinal stenosis. Phys Ther 76: 187-190.

18. Katz JN, DalgasM, Stucki G, Katz NP, Bayley J, et al. (1995) Degenerative lumbar spinal stenosis: diagnostic value of history and physical examination. Arthritis Rheum 38(9): 1236-1241.

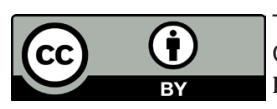

This work is licensed under Creative Commons Attribution 4.0 License DOI: $10.19080 /$ OROAJ.2017.08.555758
19. Johnsson KE, Sass M (2004) Cauda equina syndrome in lumbar stenosis. J Spinal Disord Tech 17(4): 334-335.

20. Fraser S, Roberts L, Murphy E (2009) Cauda equina syndrome: a literature review of its definition and clinical presentation. Arch Phys Med Rehabil 90(11): 1964-1968.

21. Obeagu EI, Obeagu GU, Chijioke UO, Ofor IB, Amilo GI (2017) Analysis of Alterations in Selected Haematological Parameters of Ascariasis Patients in Umudike, Abia Stae, Nigeria. Ann Clin Lab Res 5(3): 193.

22. Obeagu EI, Obeagu GU, Amilo GI, Ekelozie IS (2017) Evaluation of Haematological Parameters in Bount's Disease in Enugu, Nigeria. Journal of Biotechnology 3(9): 72-74.

23. Obeagu EI, Azuonwu O, Didia BC, Obeagu GU. Evaluation of Impact of Graves Disease on some Selected Haematological Markers among Subjects in Enugu, Nigeria. Blood Res Transfus J 1(4): 555568.

24. Obeagu EI, Amilo GI, Obeagu GU, Ugwuja SE, Agbo EA (2017) Evaluation of Impact of Level of Prostate Specific Antigen on Haematological Parameters of Men in Owerri, Nigeria. J Biomed Sci Appl 1(1): 3.

\section{Your next submission with Juniper Publishers will reach you the below assets}

- Quality Editorial service

- Swift Peer Review

- Reprints availability

- E-prints Service

- Manuscript Podcast for convenient understanding

- Global attainment for your research

- Manuscript accessibility in different formats

( Pdf, E-pub, Full Text, Audio)

- Unceasing customer service

Track the below URL for one-step submission https://juniperpublishers.com/online-submission.php 